\title{
The idea of the Biblical economics: Utopia or chance in the face of the contemporary transformations of the sphere of work
}

\begin{tabular}{|c|c|}
\hline \multicolumn{2}{|c|}{$\begin{array}{l}\text { Author: } \\
\text { Piotr Kopiec }{ }^{1,2} \text { (D) }\end{array}$} \\
\hline \multicolumn{2}{|c|}{$\begin{array}{l}\text { Affiliations: } \\
{ }^{1} \text { Ecumenical Institute, } \\
\text { John Paul II Catholic } \\
\text { University in Lublin, Poland }\end{array}$} \\
\hline \multicolumn{2}{|c|}{$\begin{array}{l}{ }^{2} \text { Department of New } \\
\text { Testament Studies, Faculty } \\
\text { of Theology and Religion, } \\
\text { University of Pretoria, } \\
\text { South Africa }\end{array}$} \\
\hline \multicolumn{2}{|c|}{$\begin{array}{l}\text { Research Project Registration: } \\
\text { Project Leader: } \\
\text { A.G. van Aarde (D) } \\
\text { Project Number: } 2334682\end{array}$} \\
\hline \multicolumn{2}{|c|}{$\begin{array}{l}\text { Description: } \\
\text { This research is part of the } \\
\text { research project, 'Biblical } \\
\text { Theology and Hermeneutics', } \\
\text { directed by Prof. Dr Andries } \\
\text { van Aarde, Post Retirement } \\
\text { Professor and Senior } \\
\text { Research Fellow in the Dean's } \\
\text { Office, Faculty of Theology } \\
\text { and Religion, University of } \\
\text { Pretoria. }\end{array}$} \\
\hline \multicolumn{2}{|c|}{$\begin{array}{l}\text { Corresponding author: } \\
\text { Piotr Kopiec, } \\
\text { petrko@kul.pl }\end{array}$} \\
\hline \multicolumn{2}{|c|}{$\begin{array}{l}\text { Dates: } \\
\text { Received: } 21 \text { June } 2018 \\
\text { Accepted: } 02 \text { Nov. } 2018 \\
\text { Published: } 11 \text { Feb. } 2019\end{array}$} \\
\hline \multicolumn{2}{|c|}{$\begin{array}{l}\text { How to cite this article: } \\
\text { Kopiec, P., 2019, 'The idea } \\
\text { of the Biblical economics: } \\
\text { Utopia or chance in the } \\
\text { face of the contemporary } \\
\text { transformations of the sphere } \\
\text { of work', HTS Teologiese } \\
\text { Studies/Theological Studies } \\
75(4), \text { a5164. https://doi.org/ } \\
\text { 10.4102/hts.v75i4.5164 }\end{array}$} \\
\hline \multicolumn{2}{|l|}{ Read online: } \\
\hline 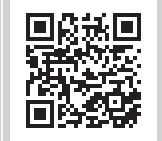 & $\begin{array}{l}\text { Scan this QR } \\
\text { code with your } \\
\text { smart phone or } \\
\text { mobile device } \\
\text { to read online. }\end{array}$ \\
\hline
\end{tabular}

The future of labour appears as one of the crucial themes of the sociological and economic reflections. Sociologists and economists proclaim a shrinking scope of labour and, consequently, a certain elitism of jobs. In their opinion, professional work will be a privilege for those who are more skilled and better educated, and those who are able to face the challenges of the rapid technological progress. This will be causing an unknown future of the reality of both common unemployment and enforced idleness, and, consequently, a deep social transformation. Questions related to human labour from the very beginning are an important field of involvement for the ecumenical movement. Theologians and churchmen of different Christian confessions, while striving for unity, put the stress on the common reflection and activity in order to counteract poverty and unemployment. An example is a biblical economics developed in the ecumenical movement, an attempt to apply both some specific biblical economic ideas and biblical general model of economic relations to the contemporary economic systems, to make them more just and more ecological. This article presents the most important elements of the biblical economics and considers their relevance for the sphere of human labour in the perspective of the oncoming crisis. Research methods encompass analysis of the presentations developed within the World Council of Churches as well as some sociological diagnosis concerning professional and wage work.

\section{Introduction}

According to many sociologists and economists, in near future the world will be facing the very deep and radical transformation of the social systems. ${ }^{1}$ Factors sparking off the oncoming changes are of diverse nature and significant. It is said about cultural processes of global westernisation on the one hand and about the clash of civilisations on the other. It is warned about the growing ethical and epistemological relativism, and, quite reversely, about the increasing religious, ethnic and cultural fundamentalism (Gellner 1992). It is indicated at the enlarging political destabilisation of the world because democracy is lacking its solid sociological background. It is deplored that values are commodifying and the logic of the market economy has a growing impact on the social relations. A survey of the contemporary tendencies reveals also some tremendous transformations related to the sphere of human work. Both technological and communication progresses bring about a new, post-industrial revolution, and new conditions set in for human activity, labour market, mass wage labour and human leisure. And the referred forecasts are rather gloomy. They reflected the threats of the digital and social exclusion, growing gap between those who are skilled to face the challenge of the more and more specialised labour market and those who are not, and finally, dangerous results of common unemployment arising from the automatisation.

From the very beginning social issues is an important field of involvement for the ecumenical movement. Theologians and churchmen of different Christian confessions, while striving for unity, put the stress on the common reflection and activity to counteract poverty and unemployment. Questions related to human labour lie therefore in the very centre of their commitment. Various ecumenical organisations, headed by the World Council of Churches, have unfolded diverse aid and development programmes addressed to the poor, in particular living in the countries of the so-called Global South; they also have developed their own theology of social and political activity and theological interpretations of social and economic 1.The article was supported by the National Programme for the Development of Humanities in Poland 2016-2019 (no 0101 /NPRH4) H26/83/2016).

Copyright: (C) 2019. The Authors. Licensee: AOSIS. This work is licensed under the Creative Commons Attribution License. Note: HTS 75th Anniversary Maake Masango Dedication. 
systems. An example is a biblical economics developed in the ecumenical movement, an attempt to apply both some specific biblical economic ideas and biblical general model of economic relations to the contemporary economic systems, to make them more just and more ecological. This article presents the most important elements of the biblical economics and considers their relevance for the sphere of human labour in the perspective of the oncoming crisis. Research methods encompass analysis of the presentations developed within the World Council of Churches (WCC) as well as some sociological diagnosis concerning professional and wage work.

\section{The world without labour: How do sociologists and economists see the future of professional work?}

The future of labour appears as one of the crucial themes of the sociological and economic reflections. Many proclaim a shrinking scope of labour and, consequently, a certain elitism of jobs. In their opinion the professional work will be a privilege for those more skilled and better educated, and those who are able to face the challenge of the rapid technological progress. This conviction has been, for instance, expressed in 1995 by Jeremy Rifkin, one of the most prominent American economists and journalists, who worked also as an advisor of the EU. In his broadly quoted, though also broadly criticised, book The End of Work, he firmly stated that

$[W]$ e are entering a new phase in world history - one in which fewer and fewer workers will be needed to produce the goods and services for the global population. (Rifkin 1995:15)

He admitted his statement would be a shadow of an optimistic narration spread up to now in the capitalist world:

$[F]$ or more than a century, the conventional economic wisdom has been that new technologies boost productivity, lower the costs of production, and increase the supply of cheap goods, which, in turn, stimulates purchasing power, expands markets, and generates more jobs. (Rifkin 1995:xvi)

In his opinion, this promising assumption is nowadays clashing with the observation that new technologies will be rather causing a growing insufficiency of jobs.

Unlike many other prophets of the future of labour, Rifkin, however, 20 years after he published his bestseller book, is far from spreading doom and gloom. Rather he sees the potential to enter into the new era, when societies will be freed from scarcity and labour coercion and human work will be performed as one's creative act. It seems that the American economist is dreaming about turning away what Marx has defined as the alienation, 'the process whereby the workers are made to feel foreign to the products of their own labour' (Felluga 2015:15). Rifkin has picturesquely expressed his hope that:

$[A]$ half century from now, our grandchildren are likely to look back at the era of mass employment in the market with the same sense of utter disbelief as we look upon slavery and serfdom in former times and he added that:

[T] he very idea that a human being's worth was measured almost exclusively by his or her productive output of goods and services and material wealth will seem primitive, even barbaric. (Derbyshire 2015)

This vision of the future world must be preceded by a preparatory period, when a new economic system, driven by the technological progress, will require a great number of skilled and professional workers, to introduce intelligent technology. Rifkin even tries to list the most important sectors of this new economic model, when counting:

[T] he maturation of the Communication Internet, the conversion of millions of buildings into renewable energy micropower plants, the reconfiguration of the electricity grid into a green Energy Internet, and the changeover to an automated Logistics and Transportation Internet. (Derbyshire 2014)

It is worthwhile to mention that this hopeful scenario is directly following famous vision of John Maynard Keynes, who, almost a hundred years ago, was also proclaiming a new worldly economic system freed from labour coercion (Skidelsky \& Skidelsky 2013:18).

Rifkin's visions, however, seem to be next to impossible. Sociological and political debates consider rather less optimistic prognoses of the future order (or, better to say, disorder). Some claim we are in for the dangers of social turbulences caused by the diminishing employment on the one hand and the growing social polarisation on the other. Some worry about the psychological and anthropological consequences of enforced idleness that would be caused by the lack of real need of work. Some compare, nowadays, social conditions with the epoch of early capitalism and remind the pivotal significance of technological transformations for changes in human life on a vast scale and, consequently, for emergence of bold new ideologies, like communism or fascism with their horrifying results. Some blame the contemporary meritocratic elites to be reluctant to take any responsibility for the social issues (Bauman 2006:23). Some are frightened by the threats of deskilling, the phenomenon that:

$[M]$ ay result when a job is automated or when a more complex job is fragmented into a sequence of easily perform units and less mental labour is required of workers and jobs become routinized and boring. (Andersen \& Taylor 2008:484)

And finally some make attempts to find a balance between jobs proclaimed to be vanishing and those emerging as a result of technology.

Regardless of the imagined scenarios for the future of work, societies must prepare for the oncoming revolution. Moreover, most of the predictions addressed to the sphere of work suggest that dominative economic paradigm of the market economy must be rejected to avoid the dire visions of the social, cultural and ecological calamities, inspiring today's science fiction movies. Both the market economy and technological progress deepen the social inequalities between and within societies and make the gap more and more impassable. 


\section{The meaning of the biblical economics}

The term biblical economics may be a little bit confusing. For theologians, the notion of economy refers primarily to the God's plan of salvation, as it is stated in the Catechism of the Catholic Church:

\begin{abstract}
The Fathers of the Church distinguish between theology (theologia) and economy (oikonomia). Theology refers to the mystery of God's inmost life within the Blessed Trinity and 'economy' to all the works by which God reveals himself and communicates his life. Through the oikonomia the theologia is revealed to us; but conversely, the theologia illuminates the whole oikonomia. God's works reveal who he is in himself; the mystery of his inmost being enlightens our understanding of all his works. So it is, analogously, among human persons. A person discloses himself in his actions, and the better we know a person, the better we understand his actions. (Point 236)
\end{abstract}

The notion of economy has therefore been strictly linked to theology. In this perspective, a Christian, when seeing the world through the lens of the Holy Scripture, understands historical processes as reflecting the economy of God. Yet, theologians must also consider economy in its more secular and autonomous dimension, which is being described by economics, a science that is traditionally defined, following Alfred Marshall, as 'a study of mankind in the ordinary business of life' (Marshall 2006:1). Economics thus provides the hermeneutics of reflection on the mechanisms driving human activity and social organisation. In the theological perspective, both meanings are neither disjunctive nor excluding, rather the 'secular' economics derive from the theological background. Van Drimmelen states, this intrinsic bond is clearly reflected in the mystery of Eucharist: 'link between "daily bread" and the bread of the Eucharist illustrates the inseparable connection between the divine economy and the secular economy, the spiritual and the material' (Van Drimmelen 1998:xii).

Thus, the biblical economics, as here presented, refers to the interpretation of the general paradigm of socio-economic relations enclosed in the Bible and, specifically, to some particular economic strategies, mostly from the Old Testament, that highlight a model of economic relations in the Holy Scripture. Since several decades the idea is being developed in the works of the WCC and other ecumenical as well as inter-church organisations and, consequently, it is exercised in their sharp criticism of the contemporary social and political order driven by the logic of market economy and applied to construct an alternative model.

The idea of biblical economics stems from the primary observation that both Old and New Testament contain many fundamental ideas concerning economic order:

The Old Testament is full of rules given by God for the management of the household, the economy, of the people of Israel. The prescriptions for the Sabbath, the Sabbath year and the jubilee year are probably among the best known.
These covenantal obligations aimed at safeguarding the creation and protecting the most vulnerable people in society. (Van Drimmelen 1998:xiii)

The economic model contained in the God's commandments has therefore both normative and axiological character, given by God to the people chosen from the mankind that became corrupted after the original fall. Unlike the market economy, which is declared to be 'natural', even though this naturalness is, theologically speaking, containing the sin, the biblical economy is not 'natural', but 'extra-natural', referring to God's plan of salvation for the sinful mankind. The question of naturalness is here of primary importance, as the logic of the market seems to be legitimised by the claiming of being natural. According to David Loy (1997), this claim has become a moving force to make market capitalism a new religion with its own secular dogmas and consumer liturgy; this economic religion:

[I]s based on two counterintuitive but widely accepted propositions: that it is right and just (which is why 'the market made me do it' is acceptable as a defense of many morally questionable activities); and that value can be adequately signaled by prices. (p. 277)

Nevertheless, regardless of the debate on the normative force of naturalness and, consequently, regardless of the question whether 'the natural' is ethically good or wrong, the ecumenical teaching on economy opposites strongly the logic of the market capitalism with its most important principles: the one about an invisible hand of the market, the one that declares the profit to be an autotelic value of all economic actions and, finally, the one that sees competition as the general regulation mechanism of economy. As Van Drimmelen noticed, 'some of the household rules given by God were rather radical, apparently because free market forces alone do not create economic justice' (Van Drimmelen 1998:xiii). Christians cannot therefore confine themselves within the logic of the market, with its would-be naturalness. They rather must constrain the principles of both profit and competition to their narrow economic sphere and must not let them get out as the general rule of social order. This is one of the key tasks of Christian churches reflected by the God's commandments.

Both the pretention of market economy to embrace the wholeness of human life and a delusion that it is free of domination became also a crucial point of the criticism by Douglas Meeks, an American theologian, who published a bestseller book God the Economist: The Doctrine of God and Political Economy (Meeks 1989:15). In his work he considers many essential questions concerning relations between Christianity, theology and economy; he also makes attempts to display the very nature of Christian understanding of economy. It is worth to notice that he looks at the etymological questions, particularly at the notion of oikos, which had meant 'house' or 'household' and which has become the stem for both notions of oikonomia [economy] and oikoumene [ecumenia]. According to Meeks, the term of oikos has three meanings in the Bible. The first one refers to the household given to people by God, the second to the area where God's creation should live in symbiosis according to God's will and 
the third one has a more normative character - it is the world, understood as the God's household, that is ruled according to the values of justice and peace. A common background of both economy and ecumenia may be understood as a theological imperative of striving for just and peaceful socioeconomic order (Raiser 2002:49).

\section{The meaning of the Sabbath and jubilee year}

As Van Drimmelen reminds, perhaps the most conspicuous illustrations of biblical economics are Sabbath, Sabbath year and jubilee year. Even though the text from the Bible 'cannot serve as a prescriptions for modern economic life', 'the Sabbath, Sabbath year and jubilee year offer a powerful vision for Jews and Christians reflecting about economic issues' (Van Drimmelen 1998:128). Sabbath is perhaps the most obvious motif as well as value, deeply embedded in religion, culture, law and economy. The ecumenical economist has differentiated two dimensions concerning the meaning of Sabbath: the theological and the social. The first one stems from the fact that 'God is Creator of all things and like God we have to cease work on the seventh day' (Van Drimmelen 1998:128); the second derives from the Exodus and makes us aware of a primordial intuition that 'stopping work at regular interval liberates us from slavery' (Van Drimmelen 1998:128). The social meaning of Sabbath enables us to reveal the liberating power of God in the human history.

The meaning of Sabbath year is to be derived from the text of Exodus:

For six years you may sow your land and gather in its produce. But the seventh year you shall let the land lie untilled and unharvested, that the poor among you may eat of it and the beasts of the field may eat what the poor leave. So also shall you do in regard to your vineyard and your olive grove. (Ex 23:10-11)

Van Drimmelen distinguishes three complementary elements in the content of the term. Firstly, the Sabbath year has a strong reference to poverty, as the poor 'can share in the fruits and produce of the land' (Van Drimmelen 1998:129). Secondly, the text has also both agricultural and ecological dimension; it is, therefore, also of technical character. Thirdly, it puts the stress on the fundamental premise of God's ownership of land, as it is expounded in the Psalm 21: 'The earth is the Lord's, and all it contains, the world, and those who dwell in it'.

The above-mentioned elements are rather general, yet for the theme of biblical economy there is also a more particular question that is of high importance. This is the release of debts as it is explained in the Book of Deuteronomy:

At the end of every seven-year period you shall have a relaxation of debts, which shall be observed as follows. Every creditor shall relax his claim on what he has loaned his neighbour; he must not press his neighbour, his kinsman, because a relaxation in honour of the Lord has been proclaimed. You may press a foreigner, but you shall relax the claim on your kinsman for what is yours. (Dt 15:1-3)

Even though the practice of the release of debts was known at the time, as Van Drimmelen notices, 'during their first year of reign, Mesopotamian kings often cancelled debts, released slaves and returned land seized by creditors' (Van Drimmelen 1998:130), the Book of Deuteronomy raised it to be the law of God, and not only a random act of grace of a ruler. The obligations related to the jubilee year are similar to those of the Sabbath. Every 50 years land should have been lying fallow, and the slaves as well as debts should have been released.

Regardless of whether the laws of Sabbath and jubilee years were followed by the Old Testament Israel, and regardless of the doubts of some historians concerning a uniqueness of these laws, the theological assumption is crucial that economic order must not be left free and God's commandments refer also to the social questions of poverty, slavery and scarcity. Both Sabbath and jubilee years mean continuous economic renewal that would mitigate destroying results of economic activity and their significance derives from God's commandment.

\section{The significance of contemporary work transformations}

Points 1 and 2 of article 23 of the Universal Declaration of Human Rights proclaim that 'Everyone has the right to work, to free choice of employment, to just and favourable conditions of work and to protection against unemployment' and 'everyone, without any discrimination, has the right to equal pay for equal work'. Quite apart from the discussion whether the social dimension of the human rights is realistic or not, it is to be insisted that in most countries of the world the right to work without any discrimination is far from abiding. Van Drimmelen (1998) noticed that

$[I] \mathrm{n}$ the South unemployment or underemployment means absolute poverty, hunger, illiteracy, poor health and a short life expectancy. In the North, it is often accompanied by social exclusion, alcoholism and drug abuse, crime, depression, disintegration of families and communities, sometimes even suicide. (p. 75)

According to the social problem theory, unemployment is regarded as causing serious social effects. For the ecumenical movement, the sphere of work is the principal field of commitment, and, it must be reminded, it was so from the very beginning (let us recall that name of the first ecumenical organisation 'Life and Work').

The biblical economics, as unfolded within the WCC, declares the work to be one of the principal elements of the Christian vision of man and society. In the second account of creation, when asking to give names to animals, man is regarded as the co-operator of God's process of creation. The premise that only man is capable of 'tilling the earth' and 'subduing it' makes him distinguished from the rest of creation. Thus, work is the constitutive factor of man's subjectivity and personality. Yet as the results of the original sin, work got coercive as well as oppressive. It became a way to realise a human pride and self-glorification; as it relates the story about the Tower of Babel, it also became a factor of slavery. 
On the other hand, the God commandment of Sabbath affirms the right to leisure time. As Drimmelen states, 'work cannot be continuous and there should be a rhythmic alteration between work and worship' (Van Drimmelen 1998:87). Referring to the New Testament, there are only few references to the concept of work. One could recall the parable of the workers in the vineyard from the Gospel of Matthew (Mt 20:1-16) and a famous quotation of St Paul from the Second Letter to Thessalonians:

For you know how one must imitate us. For we did not act in a disorderly way among you, nor did we eat food received free from anyone. On the contrary, in toil and drudgery, night and day we worked, so as not to burden any of you. Not that we do not have the right. Rather, we wanted to present ourselves as a model for you, so that you might imitate us. In fact, when we were with you, we instructed you that if anyone was unwilling to work, neither should that one eat. (2 Th 3:7-10)

History of theological reflexion provides us also with many important contents concerning work; there are the advice of Fathers who warned against idleness or the theology of calling by Luther and Calvin or the Social Gospel movement of the 19th-century liberal Protestantism or Encyclical Letters of Leon XIII and John Paul II. Regardless of many inter- and intraconfessional theological differences, one can insist that there is much in common in the teachings of Christian churches on work. It is today clearly highlighted when comparing many documents of the churches, for instance, the preamble to the WCC programme 'Economy of Life', the one that states:

People and the Earth are in peril due to the overconsumption of some, growing inequalities as evidenced in the persistent poverty of many in contrast to the extravagant wealth of a few, and intertwined global financial, socio-economic, ecological and climate crises (...) We also grew to share a common consciousness that life in the global community as we know it today will come to an end if we fail to confront the sins of egotism, callous disregard and greed which lie at the root of these crises. (Mshana \& Peralta 2010:1)

This criticism converges with the one of the Apostolic Exhortation 'Evangelii Gaudium' by Pope Francis that insists:

$[I] \mathrm{n}$ this system, which tends to devour everything which stands in the way of increased profits, whatever is fragile, like the environment, is defenseless before the interests of a deified market, which become the only rule. (Point 55)

The vision of work developed within the ecumenical movement could make a crucial contribution to the contemporary threats that resulted from the transformations of the economic and social conditions of professions and jobs. A common criticism of today's socio-economic order, as it is expressed by the Catholic Church and the WCC, puts the stress onto the most intrinsic nature of the modern-day crises sparking poverty, unemployment and social conflicts. Christian theology appears as claiming that the deep transformation of the economic system is the one that rejects the universal commodification of all values. It provides the solutions to face the challenges of the oncoming conditions of work, the future of increasing unemployment and broad social exclusion (Phillips 2005:129) on the one hand and the growing social importance of the meritocratic elites on the other. According to the documents of the Christian churches, a convergence of the market economy and the technological progress will destroy the intrinsic bound between men's creative subjectivity and socio-economic paradigm of work and deeply contradicts the very human nature.

The biblical economy, as here presented, is not a sort of sociology that would consider models of social relations and social structures, rather it reflects a strong conviction that society and economy, when left entirely unconstrained, will always be going away from the social justice and solidarity. This results from the collapsed human condition after the original fall. Economisation of the social life, when perceived as domination of economical calculations above culture and religion, creates the social gap of richness on the one hand and poverty on the other. Economy always needs cultural and religious corrective mechanisms to avoid marginalisation of those who are not able to face the challenge of social competition. The economic models contained in the Bible provide such methodological tools.

\section{Acknowledgements Competing interests}

The author declares that he has no financial or personal relationship(s) that may have inappropriately influenced him in writing this article.

\section{References}

Andersen, M. \& Taylor, H., 2008, Sociology. Understanding a diverse society, ThomsonWadsworth, Belmont.

Bauman, Z., 2006, Płynna nowoczesność [Liquid modernity], Wydawnictwo Literackie, Kraków.

Derbyshire, J., 2014, 'Jeremy Rifkin: Intelligent technology and the future of human labour', Prospect, pp. 6-8.

Gellner, E., 1992, Postmodernism, reason and religion, Routledge, New York.

Felluga, D., 2015, Critical theory. Key concepts, Routledge, London.

Loy, D., 1997, 'The religion of the market', Journal of the American Academy of Religion 65(2), 272-283. https://doi.org/10.1093/jaarel/65.2.275

Marshall, A., 2006, Principles of economics, Abridged Edition, Cosimo Classic, New York.

Meeks, D., 1989, God the economist: The doctrine of god and political economy, Fortress Press, Minneapolis, MN

Mshana, R. \& Peralta, A., 2010, Economy of life. Linking poverty, wealth ad ecology, WCC Publications, Geneva.

Phillips, D., 2005, Quality of life: Concept, policy and practice, Routledge, New York.

Raiser, K., 2002, For a culture of life. Transforming globalization and violence, WCC Publications, Geneva.

Rifkin, J., 1995, The end of work. The decline of the global labor force and the dawn of the post-market era, A Jeremy P. Tarcher/Putnam Book, New York.

Skidelsky, E. \& Skidelsky, R., 2013, How much is enough. Money and the good life, Penguin Books, London.

Van Drimmelen, R., 1998, Faith in the global economy. A primer for Christians, WCC Publications, Geneva. 